\title{
History, Knowledge, and Sustainable Economic Development: The Contribution of John Stuart Mill's Grand Stage Theory
}

\author{
Giorgos Meramveliotakis * and Manolis Manioudis
}

check for updates

Citation: Meramveliotakis, G.;

Manioudis, M. History, Knowledge, and Sustainable Economic Development: The Contribution of John Stuart Mill's Grand Stage Theory. Sustainability 2021, 13, 1468. https://doi.org/10.3390/su13031468

Academic Editor: Panagiotis

E. Petrakis

Received: 3 January 2021

Accepted: 26 January 2021

Published: 31 January 2021

Publisher's Note: MDPI stays neutral with regard to jurisdictional claims in published maps and institutional affiliations.

Copyright: (c) 2021 by the authors. Licensee MDPI, Basel, Switzerland. This article is an open access article distributed under the terms and conditions of the Creative Commons Attribution (CC BY) license (https:// creativecommons.org/licenses/by/ $4.0 /)$.
Department of Accounting and Finance, Neapolis University Pafos, Paphos 8042, Cyprus; m.manioudis@nup.ac.cy

* Correspondence: g.meramveliotakis@nup.ac.cy

\begin{abstract}
The aim of this paper is to sketch out the idea for a grand theory in development studies as the necessary research field for fruitful historical interdisciplinary, arguing that Mill's stage theory provides such a powerful theoretical framework able to contextualize, develop, and integrate the multiple, diverse, and middle-range contemporary strands in development studies. Second, an attempt is made to reconstitute Mill's stages theory of economic development placing it at the center of his political economy. We claim that Mill's theory of economic development implies that the dialectical relation between knowledge/innovation (human capital) and nature (natural capital) accelerates the course of economic change. In Mill's analysis, the dialectical relation between knowledge and nature penetrates through culture, which is regarded by Mill as a structural element of each stage of economic development. By highlighting the importance of knowledge in the transition between different stages of economic development, and by proposing a reassessed interpretation of Mill's stages theory of economic development, we propose that in Mill's political economy both innovation and nature play a pivotal role in accessing sustainable economic development.
\end{abstract}

Keywords: development; grand theory; history; knowledge

\section{Introduction}

The recent global financial meltdown followed by today's covid-19 pandemic crisis has raised increasing concern for the urgent issues of the day. In such times, many previously taken for granted theories, perspectives, and analyses of the workings of society are starting to be challenged. In particular, the efficiency of free markets is put into question and the accompanying conventional thinking of economic development and sustainability no longer appears as a "there is no alternative" approach.

Within this context, two new imperatives seem to emerge for economic science, in general, and for the development studies, in particular. First, there is a growing need for more historical depth in economic analysis in order to fully grasp the genesis of the contemporary events. Although various specific historical case studies that reflect contemporary economic dimensions have been a frequent attribute in recent development research, Rowlinson et al. [1] aptly observe "saying that time matters is not the same as saying history matters". The latter implies that today's phenomena and future operations are involved and shaped by long-term historical trends. Second, there is also a need for reconfirmation and rejuvenation of the fundamental interdisciplinary feature of development studies. A deeper understanding of the variety of factors-economic, political, institutional, cultural, and psychological — that affects, reshapes, and drives the economic development calls for a theory that focuses on those multiple factors. Thus, a coherent integration of various disciplines-including economics, sociology, politics, and psychology-is a sine qua non condition for the validity of the analysis. However, since the 1990s, publications in development studies' leading journals have shown a limited interdisciplinary interaction in development research [2], while, on the other hand, complex development issues and problems are best addressed and analyzed by integrating multiple disciplines (see, 
inter alia, [3-5]). The effectiveness of such interdisciplinary endeavors in turn is based on theoretical perspectives that involve a coherent integration rather than a mere summation.

Given the aforementioned imperatives, Mills' grand stage theory can serve as fundamental bedrock for the development studies. It offers valuable insights into both the broad sweep of human history and to the historical evolution of social development. Mill thought of history as highly as theory. More specifically, he develops an explicit theory of history to understand how societal development takes place. His theory interprets the historical course of economic progress, and in Mill's hands it is transformed into a compact theory of economic development. Furthermore, Mills' theory offers a powerful interdisciplinary approach to the development studies, as his analysis is a synthesis of a variety of influences. Mill's research interests include political economy, political philosophy and theory, psychology, the methodology of social sciences, and even sociology. As such, he provides a grand theory, one that consists as a robust platform for combining historical depth and interdisciplinary breadth. Mill follows the outline of Comtean Dynamics, which is seated on the notion of progress, and by commemorating Adam Smith and the Scottish historical school, sketches out, in the "Preliminary Remarks" of his Principles of Political Economy (1848), a prefatory (however compact) theory of how historical change takes place in the longue durée. His theory of economic development illustrates the transition from hunting to pastoral societies and from agriculture to commerce and industry through a progressive philosophy of history. We strongly believe that development studies' effort to exemplify and analyze the contemporary challenges will be considerably enriched and strengthen if they systematically engage Mill's grand theory.

The notion of sustainable development has been popularized after the publication of the Brundtland Commission Report by the World Commission on Environment and Development [6], where sustainable development was defined as " ... development that meets the needs of the present without compromising the ability of future generations to meet their own needs". The notion is based on the fundamental idea that each generation should bequeath to its successor at least as large a productive base as it inherited from its predecessor [7]. More specifically, economic interpretations of sustainability focus on the economic opportunities and thus the level of economic welfare that each generation inherit to the following one [8]. Consequently, it is argued that society should decide how to manage the today's available total capital stock (including also the natural capital) in order to increase and enlarge the current economic activities and opportunities and the overall society's welfare for the future generations [9]. In this context, there is a clear demarcation line between the notions of economic development and economic growth. The former refers to the size of the economy, notably measured by the GDP indicator, whereas the latter indicates the general qualitative characteristics (i.e., social and environmental factors) involved and affected by economic activity $[10,11]$. In this regard, sustainable economic development is contingent upon the organizations, institutions, and policies that aim to increase and enhance the wealth in ways that guarantee environmental, social, and economic well-being over time [12-14]. For instance, policies for more stringent environmental rules, control of corruption, and lower corporate taxes encourage and facilitate environmental innovations by enhancing the technical efficiency of firms and paving the way to sustainable economic development [15].

The aim of this paper is first to briefly elaborate on the idea for a grand theory in development studies as the necessary research field for fruitful historical interdisciplinary, and we argue that Mill's stage theory provides such a powerful theoretical framework able to contextualize, develop, and integrate the multiple, diverse, and middle-range contemporary strands in development studies. Second, an attempt is made to reconstitute Mill's stages theory of economic development, placing it at the center of his political economy. We claim that Mill's theory of economic development implies that the dialectical relation between knowledge/innovation (human capital) and nature (natural capital) accelerates the course of economic change. By highlighting the importance of knowledge in the transition between different stages of economic development and by proposing a reassessed 
interpretation of Mill's stages theory of economic development, we propose that in Mill's political economy both innovation and nature play a pivotal role in accessing sustainable economic development. Relying on a critical discursive analysis as the analytical method used, we attempt to highlight the analytical tools and concepts of Mill's grand stage theory that can enrich and expand the explanatory strength of the current mid-range theories of development. At its base, such a discursive approach provides additional leverage in exploring in more depth historical pathways to development, and it proposes a more holistic and interdisciplinary perspective to the study of development. Thus, our working hypothesis suggests that Mill's grand stage theory can be used to enhance the analytical explanatory power of the current mid-range theories of development. Consequently, the objectives of our research are first to attempt to demonstrate the usefulness of a grand theory into the current state of mid-range theories of development and second to show that Mill's grand stage theory could serve as an exemplar for the purposes at hand.

\section{The Usefulness of a Grand Theory}

We propose that contemporary societal and developmental problems call for adopting a more historical and interdisciplinary analytical approach. In this vein, grand theories offer the necessary methodological and analytical framework in order to integrate and conceptualize in a coherent and vibrant way the various middle-range theories. Grand theories operate at a more abstract level of analysis and involve the abstract conceptual systems and analyses that focus on the fundamental phenomena of the discipline, while middle-range theories are more grounded to earth, elaborating more concrete concepts and are "intermediate to the minor working hypotheses evolved in abundance during the day-by-day routine of research, and the all-inclusive speculations comprising a master conceptual scheme" [16]. It should be stressed that the notion of "middle-range theory" was first introduced by sociologist Robert Merton as a critique to Talcott Parson's grand (abstract) theorizing [17].

The fundamental characteristic of middle-range theories, as opposed to a grand theory, is both the rejection of abstract general laws and an all-embracing theory. For instance, Boudon [18] rejects the usefulness of a grand theory on the grounds of the "hopeless and quixotic" efforts "to determine the essential feature of all social structure" or determine basic laws "that would be sufficient to analyze all social phenomena". Although no one can disagree on the fruitless attempt to discover a theory that aims to analyze all social phenomena, Boudon's rejection seems to be based on the erroneous identification of grand theory with universalism. Moreover, having as a point of departure the empirical observation (some observable stylized facts), and via an empiricist methodology, middlerange theories conclude with the analytical specificities of the initially observable facts [19]. Because of empiricism, and the application of positivist methodology, these theories usually apply intermediate concepts that are of a pre-theoretical nature and may skip and neglect any search for a less obvious but probably more important submerged content [20].

However, it is almost impossible to erect a comprehensive, robust, and operationally efficient theory without any reference to a more general analytical framework. Thus, grand theory is the unified theory that provides an analytical and methodological framework for systematic development and the connection of a set of middle-range theories. Subsequently, grand theory and middle-range theories should be considered as complementary (rather than mutually exclusive), as the latter can be derived from the former [21]. It should be stressed that the grand theory should not be conceived as this kind of theory that involves all-encompassing universal truths, that purports to explain everything, but it consists the analytical approach that concerns the larger explanatory frames. In this vein, based on the Lakatosian epistemology, Vidal et al. [22] propose a progressive grand theory, operating as a master research program: "grand theory is progressive and legitimate when developed through the elaboration of middle-range theories that solve empirical puzzles while systematically defending and revising core assumptions and propositions in a way that expands and enriches the overarching theory, rather than restricting that theory via 
ad hoc stipulations. Progressive grand theories have the potential to inform and integrate both inductive and deductive positions."

Although development studies as such should involve grand narratives, broader explanatory frames, there is an apparent steady trend in the recent decades for far more middle-range theories that gradually and systematically shift the attention to the contextual or situational aspects of development. This means that the vast majority of contemporary development problems are usually addressed by middle-range (micro) theories, based on realist and positivist methodology, striving to discover more efficient policies. While, on the one hand, this trend may generate useful empirically rich context-specific details, on the other hand without a substantive engagement with a broader theory, this (extreme) sensitivity to the specific may hinder the advance of this essential knowledge necessary to understand the contemporary world in its totality.

\section{Mill's Theory of Economic Development: Understanding Progress through Crisis?}

John Stuart Mill is considered as one of the last representatives of the classical school of political economy. His high erudition renders him a highly influential figure in the midnineteenth century. Mill's stages theory of economic development makes up a forgotten but important part of his political economy, being an interlude between the classical period of political economy and neoclassical hegemony.

Mill understands the course of economic development in typical progressive terms. Progress plays a pivotal role in interpreting his views regarding economic development. His theory of the economic development dynamic picture includes environmental, intellectual, class, and cultural elements [23]. In Mill's pluralistic approach, these elements are interwoven through Ariadne's mito of progress. Mill, as a typical Enlightenment offspring, believes that progress is an evident feature of modern (European) civilization. His views are illustrative of this:

The progress of modern civilization [ ... ] has lasted, and remained steadily progressive, through fifteen centuries; which no other civilization has ever done [24].

Mill moves against Vico's cyclical conceptualization of historical time and observes that "the history of our species looked at as a comprehensive whole, does exhibit a determinate course, a certain order of development" [25]. His progressive views are even more explicit in his discussion of Michelet's The History of France (1833) in which he notes that:

However, Mill is ready to concede that progress is not an immutable element of history as frequent regressions detain the course of progressive development [26]. According to his analysis, regressions are the evident outcome of critical periods which are transitive between two discrete organic periods. Mill elaborates the distinction between "organic" and "critical" periodization through the influence of both Comte and Saint-Simonians. This fact renders his approach more complicated in comparison to the philosophy of both the Scottish historical school and classical Utilitarianism. In Mill's analysis, the organic period resembles Adam Smith's natural progress of things when "the material interests of the community, are managed by those of its members who possess the greatest capacity for such management [and] Individual ambition struggles to ascend by no other paths than those which the law recognizes and allows" [27]. In contrast, a critical period is associated with a transitional state of things and appears when the society has "outgrown old institutions and old doctrines" and has "not yet acquired new ones". In these circumstances, "Society demands, and anticipates, not merely a new machine, but a machine constructed in another manner". Thus, Mill's approach cannot be gleaned as a deterministic course of unremitting improvement. Crisis and transgressions are frequent obstacles in human development and are connected with the dialectical relation between "organic" and "critical" periods. According to Mill, the road to progress is tough, uncertain, and full of chance [28].

Mill's theory of economic development is grounded the organic-critical period distinction. This framework implies a set of specific features. First, it is historically sensitive. Though Mill shares the view that each stage of economic development is characterized by certain earmarks, which prevail through its constituent parts, he accords a special place 
to evidenced history and is cautious of any pretension of accurate prediction). This trait emanates from the fact that Mill's laws of economic development are "gappy laws" which "do not mention precisely how long it takes for each subsequent stage to arrive" [29]. Mill's sensitivity differentiates his history from the "French school of historians" and from the Scottish Enlightenment which are characterized by an inelastic formulation of abstract generalizations. According to Mill, even European history does not exhibit a rigid and universal historical trajectory. Because of this, the political economist cannot formulate laws that imply a rigid, pre-determinate, and universal form of economic development. Essentially, any laws regarding the course of societal development, if such there are, must be historically specific:

If there exist such laws, and if the series of states through which human nature and society are destined to pass have been determined more or less precisely by the original constitution of mankind, and by the circumstances of the planet in which we live, the order of their succession cannot be discovered by modern or by European experience alone: it must be ascertained by a conjunct analysis, so far as possible, of the whole of history, and the whole of human nature [24].

Second, Mill's theory of history is highly Eurocentric in its spirit as he believes that "the European family of nations is the only one which has ever yet shown any capability of spontaneous improvement, beyond a certain low level" [30]. Mill's Eurocentrism is linearly connected with his political liberalism. More specifically, he understands history as the perpetual contest between custom and liberty, pointing out that as society is advancing, the influence of custom is diminishing. For him, history emanates with the attainment of literacy and intellectual progress. In his own words:

The greater part of the world has, properly speaking, no history, because the despotism of custom is complete. This is the case of the whole East. Custom is there, in all things, the final appeal; justice and right mean conformity to custom [31]).

Essentially his Eurocentrism is compatible with his philosophy of history which is "rooted in the need to justify political inequality on cultural grounds" [32]. For instance, his heretic belief that Despotism is effective in governing barbarous people and his notification that the Hindoos and the Turks, which are "two great stationary communities" [27], are illustrative instances of this type of philosophical historizing. Mill, following Smith, believes that cultural differences are a matter of (historical) contingency due to the fragmentary accumulation of human capital and the uneven economic development among nations.

Third, Mill, following Smith's stages theory and Comte's Dynamics, believes that the course of economic advancement is not universal (or linear) as some nations (like British colonies) are in the pastoral or farming stage of economic development while England is preparing to enter, according to Mill, in its "Stationary State". For Mill, these primitive, or underdeveloped, societies provide ample historical evidence of the progressive course of economic and social development, and illustrate that this development is (in general) uneven. He believes that the passage from one stage of economic development to the next is not a universal historical trend. For him:

Hunting communities still exist in America, nomadic in Arabia and the steppes of Northern Asia; Oriental society is in essentials what it has always been; the great empire of Russia is even now, in many respects, the scarcely modified image of feudal Europe. Every one of the great types of human society, down to that of the Esquimaux or Patagonians, is still extant [33].

The fourth trait also commemorates Comte and is connected with the Smithian view that each stage contains cultural, social, and economic residues of its anterior. In Mill's own words:

And above all, the character, that is, the opinions, feelings, and habits of the people, though greatly the results of the state of society which proceeds them, are also greatly the causes of the state of society which follows them [34].

Each stage of economic development cannot be analyzed in vacuo and cannot be understood apart from its place in the arrow of historical development. In Mill's theory of 
history, as in Marx's historical materialism, man "can never completely cut the umbilical cord which ties him to the past" [28]. In Mill's verba:

The facts of each generation are looked upon as one complex phenomenon, caused by those of the generation preceding, and causing, in its turn, those of the next in order [24].

Last, Mill's theory of history is grounded in the interaction between men and economic institutions. This interaction is associated with his institutional individualism [35]. According to Mill, man, in his abstract form, is animated by four distinct economic interests which accompany him from his mother's womb: accumulation of wealth, quest for leisure, consumption of luxury goods, and procreation. However, these interests are always interrelated with his non-economic instincts and his institutional (historical) framework [36]. These (esoteric) instincts of human nature are interacting with the existing institutional framework and produce recorded economic, social, political, and cultural history. For Mill, the process of this interaction is tightly associated with the transitions between economic systems. The "Stagnant State" is also possible when a critical period does not occur. Essentially a "mature" organic period often leads to a slack economic, cultural and intellectual condition and is connected with obsolete knowledge. Mill, as Smith before him, has China and Egypt on his mind, which, despite their acculturation, have not attained the commercial stage of economic development.

\section{Theorizing Economic Change Through knowledge: Between Adam Smith, Auguste Comte, and Friedrich von Hayek}

A critical key in understanding Mill's theory of economic development is to delineate how economic change really takes place. Evidently, Mill's stages theory resembles the stadial theory of the Scottish historical school while it shares Smith's immanent progressivism regarding economic development. Smith's influence impelled Mill to adapt a progressive view of human development. In his own words:

It is my belief indeed that the general tendency is, and will continue to be, saving occasional and temporary exceptions, one of improvement-a tendency towards a better and happier state [34].

Mill's liaisons with Smith are more than obvious. Thus, Mill's "stages theory of economic development" is founded on the principle of succession and progress and its central premise "is the desire of increased material comfort" which is achieved through saving [34]. However, this desire is bounded (or activated) by the progress of knowledge, and secondarily by technology. In Mill's political economy, the accumulation of human capital is the real motor of economic change. As Harris [28] points out "the movement between the different stages [is] included by the development and redirection of man's intellectual and moral faculties". Mill observes that the progress of industry depends on the progress of knowledge [34]. His view is explicit:

Every considerable advance in material civilization has been preceded by an advance in knowledge, and when any great social change has come to pass, either on the way of gradual development or of sudden conflict, it has had as its precursor a great change in the opinions and modes of thinking of society [34].

Similarly:

Polytheism, Judaism, Christianity, and Protestantism, the critical philosophies of modern Europe, and its positive science- each of these has been a primary agent in making society what it was at each successive period, while society was but secondarily instrumental in making them, each of them [ ... ] being mainly an emanation not from the practical life of the period, but from the previous state of belief and thought [34].

These views anticipate Buckle's History of Civilization, Weber's Protestant Ethic and the Spirit of Capitalism, and Hayek's The Use of Knowledge in Society. The similarities between Mill and Weber are more than explicit. For Buckle [37] the "advance of civilization solely depends on the acquisition of human intellect, and on the extent to which those acquisitions are diffused". Mill, before Hayek, stresses the importance of knowledge as diffused in society. In principle, he believes that human progression is mainly dependent on the intellectual convictions of mankind. For him, the history of human mankind is 
an intellectual history of cultural development. Mill stresses the importance of ideas and knowledge by noting that the history of Western Europe is the crystallization of three intellectual movements:

Of such we have had an example in the condition of Europe during the times immediately following the Reformation; another, though limited to the Continent and to a more cultivated class, in the speculative movement of the latter half of the eighteenth century; and a third, of still briefer duration, in the intellectual fermentation of Germany during the Goethian and Ficthean period. These periods differed widely in the particular opinions which they developed [ ... ] made Europe what is now is [31].

According to Mill, the intellectual element, in all its forms, is decisive for the promotion of historical change: "the state of the speculative faculties, the character of propositions assented to by the intellect, essentially determines the moral and political state of the community" [34]. For Mill, the transition from one stage of economic development to the next is associated with the transformation of the intellectual element of the society which all its members share in common. In his view, progress is tightly connected with the improvement of knowledge and material well-being. According to his approach, knowledge made possible both material advancement and social unity. In his own words:

Wherever there has arisen sufficient knowledge of the arts of life, and sufficient security of property and person, to render the progressive increase of wealth and population possible, the community becomes and continues progressive in all the elements [31].

Mill's theory of economic development resembles Hegel's cunning of reason, as knowledge is the prime mover of both material advancement and cultural improvement. At the same time, technology may be regarded an important requirement of economic development, but Mill himself, contrary to Marx, "considered it to be an expression of man's improvement as a moral agent" [28]. Mill's theory of economic development, as is delineated in the Preliminary Remarks of his Principles of Political Economy, reflects Comte's epistemological idealism, according to which history is a progressive trend of intellectual and scientific development implemented through three stages. In reality, Mill's theory of economic development reflects an inborn idealism, as ideas always precede material processes. However, at many points, Mill's idealism contradicts with materialistic views. For instance, the Agricultural Revolution, which is connected with the transition from the farming to the commercial stage of economic development, is connected with new farming ideas and techniques which were the result of demographic pressure on land through the diminishing returns of scale in agriculture. For Mill, as for Comte and Saint-Simonians, each stage of societal organization reflects a certain type of scientific knowledge, public opinion, and common belief.

Mill developed a progressive view of history which works itself through the motif of "organic and critical periods" [30]. Each stage of economic development represents an "organic period" and is seated on a dominant mode of scientific thought and knowledge (theological, metaphysical, or positive in Comte's terms). On the other hand the 'critical period' anticipates Gramsci's “organic crisis" as the transition from one stage to the next is implemented through the outbreak of a moral or social revolution which is tightly connected with the cessation of progress [38]. For instance, Mill regards the French Revolution as a mark of a transitive (critical) period. He notes that Europe "entered into the state of transition of which the first overt manifestation was the breaking out of the French Revolution" [27].

The critical period, which in Mill's analysis is the historical thread between different stages of economic development, is connected with the contestation of the dominant intellectual element and with the absence of an intellectual elite. The early Mill observes that:

The authority which sets the opinions and forms the feelings of those who are not accustomed to think for themselves, does not exist at all, or, existing, resides anywhere but in the most cultivated intellects, and the most exalted characters, of the age [27].

The transition from one stage to the next is concluded through the augmentation of knowledge and its subsequent metakenosis among more people. This diffusion goes 
manus in mani with material progress and as such renders the socialization of knowledge an evident feature of modern civilization. Mill, in a typical Hegelian fashion, believes that the progress of knowledge is achieved through the opposition of conflicting ideas and beliefs. This conflict is taking place in the "arena" of the critical period, and as such history is explained "as a succession of 'critical' and 'organic' periods" [39].

\section{Mill's Stages Theory: A Reassessment}

The Millian theory of economic development is compendiously elaborated in his great "Preliminary Remarks" of his economic locus classicus. However, this elaboration seems to be abstract and pre-typified. This section attempts to incorporate Mill's theory of economic development as is presented in his "Preliminary Remarks", with the history of property as is delineated in his Chapters on Socialism, the evolutionist political theory of his On Liberty and his anti-conformist theory of intellectual development as presented his Civilization and in his review of de Tocqueville's Democracy of America. The aim of this section is to denote that Mill's theory of history is a holistic theory of economic, social, political, natural, and intellectual development. John Stuart Mill, like his father, accepted the focal motif of the Scottish historical school, namely, the "four-stage" theory of social and economic development. The Millian theory of economic development is Scottish in nature and reproduces Smith's picture of historical evolution. Mill, as do Smith, Ferguson, Millar, and other Scottish philosophers, points out that the rude stage was followed by the pastoral stage, the shepherd stage was succeeded by that of farming and the farming stage was replaced by the commercial stage of economic development. According to Mill, recorded history is associated with the production of wealth and each stage is characterized by its (historically) formed property rights, its productive techniques and its own distributive methods. The institutionalization of property rights implies a specific form of governance in each stage of economic development. For Mill political institutions reflect economic and social circumstances.

A nation [... ] cannot choose its form of government. The mere details, and practical organization, it may choose; but the essence of the whole, the seat of the supreme power, is determined for it by social circumstances [31].

Mill's stages theory of economic development, as is exemplified in the "Preliminary Remarks" of his Principles, is connected with a "history of property" which is presented in his unfinished Chapters on Socialism (1879). In this posthumously edited essay, Mill observes that the idea of property is a historical product of custom and law, and is changed through the transformation of social, intellectual, and economic structures. Ipso facto, every generalization "must be reduced to a distinct expression and proper limits" [31]. Mill's conclusion in his Chapters on Socialism is indicative:

The idea of property is not some one thing, identical throughout history and incapable of alteration, but is variable like all other creations of the human mind; at any given time, it is a brief expression denoting the rights over things conferred by the law or custom of some given society at that time [40].

Mill understands property as a creation of human mind, and as such he connects it with the acquisition of knowledge. The variable character of knowledge is the clavis aurea of understanding the differences between societies. For Mill, the different forms of property rights in different epochs illustrate social, political, and cultural differences. According to Mill the evolution of the society is associated with the diffusion of knowledge and innovation among people and the subsequent safeguard of the natural capital. For Mill, human and natural capital are considered as prerequisites of sustainable economic development. Mill, following Aristotle, believes that human capital comprises things that exist by skill (the artificial social and economic world), while natural capital includes things that exist on their own (natural objects) [41]. There is a blending of the natural and the artificial capital. According to DesRoches:

On this account, the natural and artificial are located along a spectrum or continuum with the most natural objects being those that remain relatively detached from human 
agency and the most artificial objects are those that have been built and constructed by intentional human agents. There is a no sui generis difference between artificial and natural objects since the difference is always a matter of degree [41].

Their dialectical relation attains its peak in the "Stationary State" of economic development. During this era of economic and cultural development the socialization of knowledge and the free exchange of ideas would encourage people to innovate protecting at once their social and physical environment.

Mill notes that pre-history begins with the rude states of societal organization when people earned their subsistence by the spontaneous produce of vegetation and by the produce of hunting and fishing. Mill, as Smith and Marx, regards these organizations as pre-civilized and observes that in their savage life, "there is no commerce, no manufactures, no agriculture, or next to one" [31]. The scanty economic conditions of this early stage are crystallized in personal independence, in the absence of a developed social life, in limited knowledge, and in the lack of discipline in regard to laws [32]. The rude state of society is associated with low intellectual development as

[E]ach man's personal security, the protection of his family, his property, his liberty itself, depends greatly upon his bodily strength and his mental energy or cunning [31].

The low level of knowledge and sparse innovation lead to limited material progress as these societies have no accumulation of wealth [33]. Additionally, people of this stage are unable to tame their passions while the absence of self-restraint renders them unsuited to any form of representative government [42,43]. More specifically, people in the rude stage of economic development are characterized by inactivity, lack of aspiration, and absence of desire which are fatal hindrances to economic and moral improvement [31]. The dominant mode of thought in this stage of societal development is the fetishist version of the theological mode of thought. According to Comte, the fetishist stage is the primary phase of the theological stage of thinking and during its dominance people believe that inanimate objects have a living spirit in them. For Mill, in this stage of things only brutal Despotism is functional. Beate [32] notes that according to Mill, "Despotism and slavery are therefore the appropriate form of government for savages and history shows that almost all peoples now civilized have gone through this stage".

The rude stage is followed by the pastoral (or nomad) stage in which most useful animals are domesticated while people "do not live on the produce of hunting, but on milk and its products and on the annual increase of flocks and herds" [34]. This stage of economic development is associated with an early accumulation of both wealth and knowledge. Mill follows Smith's narration and observes that the shepherd stage is the first phase in recorded history which is characterized by inequality of possessions. In this stage, individual property rights substitute communal ownership which is the rule in the rude stage. The advancement of wealth creates new desires such as better clothing, utensils, implements, and tools. For Mill, this stage of economic development is associated with the emergence of sciences due to the leisure time characteristic in it. In the pastoral stage of social advancement, the theological mode of thought gains its polytheistic and monotheistic versions and is associated with an initial appearance of religions. In Mill's approach, the pastoral stage is connected with initial imprints of Civilization. In this stage, knowledge is exemplified in specific innovations such as the ancient wheel. For Mill, recorded history and civilization are crystallized in the emergence of both property and power. In the primitive stages of economic development, property, power, and knowledge are possessed by great men such as kings, lords, barons, etc. More specifically, power is "entirely concentrated in a small number of hands; the remainder of the people being, with few exceptions, either the military retainers and dependents of the possessors of property, or serfs, stripped and tortured at pleasure by one master, and pillaged by a hundred" [31]. According to Mill, tyrannical regimes emerge in the shepherd stage of economic development and are closely connected with the "rule power". Evidently, therefore, famous tyrants such as Genghis Khan, Tamerlane, Akbar, or Charlemagne are representative figures of the shepherd stage. As is noted, Mill's famous (and controversial) aphorism that "Despotism is 
a legitimate mode of government in dealing with barbarians" [31], is politically confined to the backward savage and shepherd stages of economic development. In the early stages of economic and societal organizations, when knowledge is limited and animal instincts are in excess, social cohesion is secured by great men who had the means of "disciplining and controlling" [31]. However, the despotism of the shepherd stage is different to that of the rude stage as is connected with guidance and not with cruel force. Mill calls it "Parental Despotism" and points out that it is associated with direct guidance which is the prime feature of the second stage of economic development. The duty of guidance continues to be confined to specific people who possess society's knowledge (aristocracy, judges, clerks, etc.). Mill cites as illustrative examples of this type of governance the 'Incas of Peru' and the 'Jesuits of Paraguay' by noting that "I need scarcely remark that leading-strings are only admissible as a means of gradually training the people to walk alone" [31]. Mill himself specifies this gradual training by illustrating the importance of "great men":

There have been in history few of these who, happily for humanity, have reigned long enough to render some of their improvements permanent, by leaving them under the guardianship of a generation which had grown up under their influence. Charlemagne may be cited as one instance; Peter the Great is another [31].

As society advances, wealth and power are diffused to the layman and the importance of great men is diminishes. In Mill's view, progress is identified with the diffusion of both property and knowledge. This diffusion is actualized through political liberties and civil rights [31]. According to Mill, in the civilized stages of economic development, individuality is enhanced and "the danger which threatens human nature is not the excess, but the deficiency, of personal impulses and preferences" [31]. The widespread diffusion of knowledge among people weakens the despotism of custom and accelerates the creative powers of liberty. In Mill's mind, progress is associated with the impoverishment of customary modes of thinking, reasoning, and acting.

Mill follows the Scottish tradition and observes that the transition from pastoral to agricultural society is tardy and not an ordered or automatic process. For him the transition is illustrated by the dominance of liberty over custom. However, the point of transition is frequently a matter of mere accident. He warns that there is always the possibility of going backwards: "towards the worse, consisting of all the follies, all the vices, all the negligences, indolences, and supineness of mankind" [31]. Mill warns us that the danger of stagnation is always on the verge of appearing. He cites as concrete historical examples, China, Egypt, and other great Asian nations which are, according to his famous phrase, among "the most melancholy facts in history" [31]. Stagnancy is the direct effect of limited knowledge and innovativeness. However, other countries, however, mainly in Western Europe, had institutions which had broken down the dominance of custom and had given place to liberty. For Mill the pressure of pasturage enabled men to support the first systematic tillage of the waste lands along them. The cultivation of fertile soils produces food which highly "exceeds what could be obtained in the purely pastoral state" [33]. The cultivation of land implies economic advancement which is associated with the emergence of new forms of governance. The surplus product, whether small or great: is usually torn from the producers, either by the government to which they are subject, or by individuals, who by superior force, or by availing themselves of religious or traditional feelings of subordination, have established themselves as lords of the soil [33].

Concrete history becomes the sine qua non of Mill's theory of economic development. According to his analysis, the diversity of methods with regard to the appropriation of the surplus product is associated with diverse modes of societal organization. Historically, the first of them is connected with the extensive monarchies in Asia (i.e., Mongols). In these historical cases, a large part of the surplus produce "is distributed among the various functionaries of government and among the objects of the sovereign's favor or caprice" [33]. In these societies, individual princes, who constitute the upper level of class structure, exchange a part of the surplus produce with luxury goods. Gradually, the demand for luxury goods: [R]aises up in the country itself a class of artificers, by whom certain fabrics 
are carried to as high excellence as can be given by patience, quickness or perception and observation, and manual dexterity, without any considerable knowledge of the properties of objects [33].

According to Mill, during the first phase of agricultural stage, due to insecurity per se, the surplus product of society is transformed into durable and towering edifices, such as the Pyramids, the Taj Mahal, and the Mausoleum at Sekundra. These societies are not un-merchandised but their merchants are either grain dealers who are buying grain from the agents of government, or money dealers. The money dealers are chiefly lending money to unfortunate cultivators, who are ruined by bad seasons and are repaid with enormous interest in subsequent harvests. Naturally the "commercial operations of both these classes of dealers take principally upon that part of the produce of the country which forms the revenue of the government" [33].

On the other hand, the agricultural communities of ancient Europe are different to those of Asia. These communities were gathered in small towns, formed either by plantation or by indirect habitation. Many of these communities, especially those which were sat on the shores of a great inland sea, recorded a rapid and brilliant cultural boom. These societies were not solely agricultural, as their position offered to them easy access to foreign ideas and inventions. In Mill's own words: when their soil was sterile, or after they had reached the limit of its capacity, they often became traders, and bought up the production of foreign countries, to sell them in other countries with a profit [33].

The limited extent of these territories, in conjunction with demographic pressure, impelled many of their inhabitants either to emigrate en masse or to form colonies with the sword of knowledge in hand. Some towns, such as Athens, took advantage of their colonies and obtained a considerable surplus of wealth. Mill, like Smith, points out that surplus accelerates the motive of their intellectual development. According to his analysis: From such surplus the Parthenon and the Propylea were built, the sculptures of Pheidias paid for, and the festivals celebrated, for which Aeschylus, Sophocles, Euripides, and Aristophanes composed their dramas [33].

However, these towns were gradually conquered by great empires with the Roman Empire being the most characteristic of them. These empires institutionalized individual property rights and legalized the substantive inequalities in both properties and possessions. However, the ill governance of the Roman Empire was the prima causa of its conquest by nomads which had skirted its northern frontiers. The disentanglement of the Roman Empire, which was a gradual and arduous process, is connected with the emergence of feudalism, which is historically the late phase of the agricultural stage of economic development. During the feudal period, which is a crucial period for the subsequent modern economic and social history of Western Europe: the population of each country may be considered as composed, in unequal proportions, of two distinct nations or races, the conquerors and the conquered: the first the proprietors of the land, the latter the tillers of it [33].

According to Mill, in the feudal period, which is connected with the widespread institutionalization of property rights and with the concentration of knowledge into a special minority of people, the primitive accumulation of the wealth of pre-modern Europe became possible. Mill accepts Smith's firm view that towns were (historically) much safer than the countryside. The movement form the countryside to towns is associated in Mill's approach with an initial diffusion of knowledge (of arts, commerce etc.) among more people. The former peasants, who obtained (bought) their freedom, immigrated to medieval cities, improved their human capital, and became artificers who "Lived by exchanging the produce of their industry for the surplus food and material which the soil yielded to its feudal proprietors" [33]. This tendency reached a climax during the mature period of the Middle Ages, when: The towns of Italy and Flanders, the free cities of Germany, and some towns of France and England, contained a large and energetic population of artisans, and many rich burgers, whose wealth had been acquired by manufacturing industry, or by trading in the produce of such industry [33]. 
The economic advancement of towns, together with the extended commerce of luxuries, propelled the weathering of feudalism. As a result, "the immediate cultivators of the soil, in all the more civilized countries, ceased to be in a servile or semi-servile state" [33]. This transition took different forms in different places and brought an end to the economic obstacles imported by compulsory labor and augmented the productive powers of laborers. Evidently, this passage favored the production and trading of conveniences and of luxuries of all kinds. In Mill's view, feudalism, in contrast to the Asiatic stage of economic development, prepared the ground for the capitalist transformation as it allowed the diffusion of wealth among people of different ranks, propelling the improvement and diffusion of human knowledge. For Mill, this diffusion was assisted by the Catholic Church which, despite its fatal faults on the whole, convinced that it was not only a beneficent institution, but the only means capable of being now assigned, by which Europe could have being reclaimed from barbarism [24].

The diffusion of wealth and knowledge brought about an increased production of food increasing the birth rate. According to Mill, this was the aurora of the commercial stage of societal organization in which the ability to maintain fleets and armies, to execute public works, either useful or ornamental, to perform national acts of beneficence [ ... ] to found colonies, to have its people taught, to do anything in short which requires expense, and to do it with no sacrifice of the necessaries or even the substantial comforts of its inhabitants, are such as the world never saw before [33].

For Mill, the leading feature of the commercial stage is that the wealth of different countries is varied to very different degrees. He believes that the economic advancement of certain countries, like Great Britain, is connected with the more just distribution of wealth to more people:

The amount of capital annually exported from Great Britain alone, surpasses probably the whole wealth of the most flourishing commercial republics of antiquity. But this capital, collectively so vast, is mainly composed of small portions; very generally so small that the owners cannot, without other means of livelihood, subsist on the profits of them. While such is the growth of property in the hands of the mass, the circumstances of the higher classes have undergone nothing like a corresponding improvement [31].

According to the Millian theory of economic development, Europe was the first territory which entered the commercial stage, due to the pluralistic character of knowledge among nations. His comment from his On Liberty is worth of quoting:

What has made the European family of nations an improving, instead of a stationary portion of mankind? Not any superior excellence in them, which, when it exists, exists as the effect not as the cause; but their remarkable diversity of character and culture. Individuals, classes, nations, have been extremely unlike one another; they have struck out a great variety of paths, each leading to something valuable; and although at every period those who travelled in different paths have been intolerant of one another, and each would have thought it an excellent thing if all the rest could have been compelled to travel his road, their attempts to thwart each other's development have rarely had any permanent success, and each has in time endured to receive the good which the others have offered. Europe is, in my judgment, wholly indebted to this plurality of paths for its progressive and many-sided development [31].

Essentially, the proximity of great nations, and the balance of power among them, produced the conditions for their subsequent cooperation, through trade, which is the sine qua non of civilization. However, the commercial stage of economic development is connected, in Mill's political thought, with the emergence of the "middle class" due to the irregular distribution of both property and knowledge. For Mill, this allocation of wealth is identical to the advancement of civilization which is associated with the breakdown of large properties. Evidently therefore, as society progresses, "the diversities in the distribution of wealth are still greater than in the production" [33]. These differences depend on physical and social causes and have to be interpreted by means of the positive scientific tool of this stage, political economy. Political economy is the crystallization of the positive stage 
of scientific thought as it is methodologically grounded on observation, experiment, and comparison. At the political level, the most direct effect of civilization is the limitation of the influence of great men as "there is not a more accurate test of the progress of civilization than the progress of the power of cooperation" [31].

The limiting influence of great individuals is directly associated with the emergence of representative government or democracy in more political terms. For Mill, the representative government is regarded as the best form of governance but only for civilized nations. According to Mill, representative government is foremost a cultural indicator. Though John Stuart Mill accepts his father's motif that "in the representative system alone the securities of good government are to be found" [44], he also notes that representative government is closely tethered to economic, industrial, and intellectual development. In Mill's political analysis, the commercial stage is connected with "The triumph of democracy, or, in other words, of the government of public opinion" [31]. Democracy is based on the "natural laws of the progress of wealth, upon the diffusion of reading, and the increase of the facilities of human intercourse" [31]. For Mill, the liberal teachings of On Liberty are connected with the diffusion of knowledge and are partially applicable to the commercial stage of economic development which is identified with the dominance of Democracy and the emergence of the national state). According to Mill, the effects of economic (and social) development are unambiguously beneficial. This is illustrated by a variety of quotes in both his Civilization and in the Considerations of Representative Government. For him, these beneficial trends could be summarized as the multiplication of physical comforts; the advancement and diffusion of knowledge; the decay of superstition; the facilities of mutual intercourse; the softening of manners; the decline of war and personal conflict; the progressive limitation of the tyranny of the strong over the weak; the great works accomplished throughout the globe by the co-operation of multitudes [45].

The majority of these benefits are connected with the emergence of the positive mode of thinking. However, civilization itself is connected with an array of pathologies. Mill is aware of them and cautions against the "disease" of unguided and unrestrained civilization [42]. These are referred to as psychological, political, economic, cultural, and even aesthetical problems. For Mill, as for de Tocqueville, the "middle class" is the cultural danger in commercial society as it constitutes the "mass" which is removed from the development of individuality which is regarded as the sine qua non of both liberty and representative government.

Thus, the liberal teachings of On Liberty and the representative democracy of Considerations of Representative Government are inappropriate for all commercial societies, especially in those which are just entered into their commercial stage. In Mill's mind, an early commercial stage is associated with a pre-positive mode of thinking. According to his views, democracies function more efficiently when citizens regard their elected officials as representatives, who are "empowered to exercise their best judgment, free from the coercion or pressure of their own constituents, in making political decisions", rather as delegates, "who simply act as a mouthpiece for the majority's will" [42]. "Economism", which is the dominant ideology of the pre-positive stage of thinking, is the womb of the low level of both mental and moral cultivation and of the intolerance towards minorities and towards any idea which is moving en converso to those of the majority. For Mill, the representation of minorities is of prime importance for the function of representative democracy:

It is an essential part of democracy that minorities should be adequately represented. No real democracy, nothing but a false show of democracy, is possible without it [31].

At the same time, in Mill's thought, the commercial stage of economic development is characterized by the confrontation of the Malthusian ghost: experience shows that in the existing state of society the pressure of population on subsistence which is the principal cause of low wages, though a great, is not an increasing evil; on the contrary, the progress of all that is called civilization had a tendency to diminish it, partly by the more rapid increase of the means of employing and maintaining labor, partly by the increased facilities opened 
to labor for transporting itself to new countries and unoccupied fields of employment, and partly by a general improvement in the intelligence and prudence of the population [40].

The commercial stage is the first stage of that public movement for the education of all ranks of people and as such is connected with demographic monitoring. However, population control, and educational diffusion, is even more efficient in the "Stationary State" which is the cornice of the commercial stage of economic development. In the "Stationary State", knowledge and natural capital imply a rich variety of economically valuable and sustainable production that are afforded to human agents, gratis [41].

According to the aforementioned analysis, Mill's (pluralistic) view of human progress impelled him to form an interesting typology of stages theory. We believe that his theoretical contribution can be used - along with the great legacy of classical political economy [14] —as a grand theory to understand the study of problems and phenomena of today's societal development. More specifically, Mill utilized a variety of elements that are transforming as society is moving from one stage to the next. These elements comprise a great variety of elements but some of them could be considered as "core". Namely, according to our narration, the most characteristic of them are (a) knowledge, (b) demography/culture, (c) natural capital, and (d) political administration. The following table (Table 1) illustrates how these elements are transformed and could lead (in the end) to sustainable economic development.

Table 1. Core elements of John Stuart Mill's Stages Theory.

\begin{tabular}{|c|c|c|c|c|}
\hline Stage & Knowledge & Demography/Culture & Natural Capital & Politics \\
\hline Hunting & $\begin{array}{c}\text { Limited and non- } \\
\text { concentrated knowledge }\end{array}$ & $\begin{array}{c}\text { Inactivity } \\
\text { Lack of aspiration }\end{array}$ & Mere subsistence & Tribal societies \\
\hline Shepherd & Accumulation of knowledge & Emergence of religions & $\begin{array}{l}\text { Domestication of } \\
\text { animals }\end{array}$ & Despotism \\
\hline Farming (feudalism) & $\begin{array}{l}\text { Knowledge is concentrated } \\
\text { on kings, lords etc. } \\
\text { Catholic Church }\end{array}$ & Demographic pressure & $\begin{array}{l}\text { New tillage techniques } \\
\text { (systematic tillage) }\end{array}$ & Monarchies \\
\hline $\begin{array}{l}\text { Commercial } \\
\text { (Capitalism) }\end{array}$ & $\begin{array}{l}\text { Diffusion of wealth and } \\
\text { knowledge }\end{array}$ & $\begin{array}{l}\text { Births' increase } \\
\text { (Malthusian trap) }\end{array}$ & $\begin{array}{l}\text { Negative externalities } \\
\text { due to the production } \\
\text { process }\end{array}$ & $\begin{array}{l}\text { Representative } \\
\text { government and } \\
\text { Liberal teachings }\end{array}$ \\
\hline
\end{tabular}

As we noted, Mill's stages theory is an open-ended process, as his course of economic history is associated with the transition from the commercial stage to the (co-operative) stationary state. According to Mill's political economy, this (ulterior) stage is associated with the perspective of sustainable economic development since low profitability coexists with knowledge's diffusion, the avoidance of the Mathusian trap, the balanced relation between natural and human capital, the development of individuality and the strengthening of democracy.

Additionally, Mill's anticipation of the Stationary state typology may be useful in several meso-range theories that serve to contextualize current economic and social phenomena in post-industrial countries. Mill's grand theory by stressing the combination between knowledge, social and natural ecosystems, and state strategy could provide the theoretical background for both policies and practices. Mill's approach could add the importance of knowledge in medium-range perspectives of economic development. According to Mill the diffusion and the harnessing of knowledge is critical to promote social, political and economic development. For example, the role of (harnessing) knowledge, as Mill observed, is crucial in directing population's control and in accelerating creative development. As such, Mill's grand theory may be extremely useful in revitalizing both meso and macro development theories. 


\section{Conclusions}

We have argued that contemporary societal and developmental problems call for adopting an alternative research program in development studies. There is an urgent need for the rejuvenation of the grand theories that are able to encompass the multiple middle-range theories, to offer a greater historical depth and provide the necessary interdisciplinarity in order to better understand and elaborate the complex and interrelated developmental dynamics. In this vein, we have sought to show that Mill's stage theory provides a vibrant grand theory that through its engagement with middle-range theories that, which solve empirical puzzles, can expand and enrich the development theory.

Mill's grand theory of economic development is one of the most interesting aspects of his political economy. Mill adapts the Scottish formalism of four stages (hunting, shepherd, farming and commercial) historical change in more idealistic terms. Comte's influence is evident here. Knowledge, as accumulated human capital, functions as the modus operatti of societal transformations. According to Mill, the accumulation and the subsequent diffusion of knowledge is crucial in transiting from one stage to the next. The importance of the intellectual element and the distinction between organic and critical period play an instrumental role in shaping Mill's views on economic development. This distinction is crucial in understanding how Mill's thoughts regarding human progress. A long-term organic period, which is not contested by a critical period leads to economic and cultural stagnancy. The "Stagnant State", which is one of the most melancholic prospects in the history of human mankind, should be avoided primarily for cultural reasons. For Mill, the "Stagnant State" is the direct consequence either of the "falling rate of profit' or of bad political administration. He holds the view that mature economies have to avoid it and prepare their entrance in the "Stationary State" of his Chapters on Socialism which is very different from the "Stagnant State" of his Principles. According to Mill's inborn optimism, the "Stationary State" implies a long-term standstill in economic activity but is connected with a more just distribution of wealth and with intellectual, moral, and scientific advancement.

At the end, it should be stressed that the discussion of the usefulness of grand theories in development studies should not be confined exclusively to Mill's stage theory. On the contrary, it is in our belief that the situation of the present day, marked by the fact that the contemporary developmental problems intensified by the covid19-pandemic and the economic depression, calls for a return to the basic questions, problems and conceptions of the classical political economy of the Scottish Enlightenment and in particular Adam Smith. In such a move, we may even come to recall that this was the tradition, which also ultimately led to the critique of political economy from Karl Marx.

Author Contributions: Conceptualization, methodology, software, validation, formal analysis, investigation, resources, data curation, writing — original draft preparation, writing — review and editing, visualization, supervision, project administration: G.M. and M.M. All authors have read and agreed to the published version of the manuscript.

Funding: This research was funded by the Neapolis University Pafos.

Conflicts of Interest: The authors declare no conflict of interest.

\section{References}

1. Rowlinson, M.; Hassard, J.; Decker, S. Research Strategies for Organization History: A Dialogue Between Historical Theory and Organization Theory. Acad. Manag. Rev. 2014, 39, 250-274. [CrossRef]

2. Mitra, S.; Palmer, M.; Vuong, V. Development and interdisciplinarity: A Citation Analysis. World Dev. 2020, 135, 1-17. [CrossRef]

3. Mehta, L.; Haug, R.; Haddad, L. Reinveting Development Research. Forum Dev. Stud. 2006, 33, 143-148. [CrossRef]

4. Lam, J.C.; Walker, R.M.; Hills, P. Interdisciplinarity in Sustainability Studies: A Review. Sustain. Dev. 2014, 22, 158-176. [CrossRef]

5. Arsel, M.; Dasgupta, A. Critique, Rediscovery and Revival in Development Studies. Dev. Chang. 2015, 46, 644-665. [CrossRef]

6. World Commission. Our Common Future; Oxford University Press: Oxford, UK, 1987.

7. Dasgupta, P. The Idea of Sustainable Development. Sustain. Sci. 2007, 2, 5-11. [CrossRef]

8. Barbier, E. Frontiers and Sustainable Economic Development. Environ. Resour. Econ. 2007, 37, 271-295. [CrossRef] 
9. Barbier, E. The Policy Challenges for Green Economy and Sustainable Economic Development. Nat. Resour. Forum 2011, 35, 233-245. [CrossRef]

10. Blakely, E.; Leigh, N. Planning Local Economic Development: Theory and Practice; Sage: Thousands Oaks, CA, USA, 2010.

11. Greenwood, D.; Holt, R. Local Economic Development in the 21st Century: Quality of Life and Sustainability; M. E. Sharpe: Armonk, NY, USA, 2010.

12. Acemoglu, D. Introduction to Economic Growth. J. Econ. Theory 2012, 147, 545-550. [CrossRef]

13. Hammer, J.; Pivo, G. The Triple Bottom Line and Sustainable Economic Development Theory and Practice. Econ. Dev. Q. 2017, 31, 25-36. [CrossRef]

14. Manioudis, M.; Meramveliotakis, G. New Institutional Economics and Economic Development: A Smithian Critique. In Bringing Microeconomics and Macroeconomics and the Effects on Economic Development and Growth; Kostis, P., Ed.; IGI Global: Hershey, PA, USA, 2020; pp. 27-40.

15. Aldieri, L.; Makkonen, T.; Paolo Vinci, C. Environmental Knowledge Spillovers and Productivity: A Patent Analysis for Large International Firms in the Energy, Water and Land Resources Fields. Resour. Policy 2020, 69, 1-7. [CrossRef]

16. Merton, R. Social Theory and Social Structure; Free Press: New York, NY, USA, 1968; p. 5.

17. Kang, N. Towards middle-range theory building in development research: Comparative (historical) institutional analysis of institutional transplantation. Prog. Dev. Stud. 2014, 14, 221-235. [CrossRef]

18. Boudon, R. What Middle-Range Theories Are. Cotemporary Sociol. 1991, 20, 519-522. [CrossRef]

19. Cartwright, N. Middle-Range Theory: Without it What Could Anyone Do? Theoria 2020, 35, 269-323. [CrossRef]

20. Mavroudeas, S. The Limits of Regulation: A Critical Analysis of Capitalist Development; Edward Elgar: Cheltenham, UK, 2012 ; p. 49.

21. Allan, K. The Social Lens: An Invitation to Social and Sociological Theory; Sage Publications: London, UK, 2006.

22. Vidal, M.; Adler, P.; Delbridge, R. When Organization Studies Turns to Societal Problems: The Contribution of Marxist Grand Theory. Organ. Stud. 2015, 36, 405-422. [CrossRef]

23. Schumpeter, J.A. History of Economic Analysis; Routledge: London, UK; New York, NY, USA, 1954; p. 518.

24. Mill, J.S. Essays on French History and Historians; Robson, J.M., Ed.; University of Toronto Press- Routledge and Kegan Paul: Toronto, ON, Canada, 1985.

25. Mill, J.S. Auguste Comte and Positivism; Kegan, Paul, Trench, Trubner, \& Co: London, UK, 1891; p. 85.

26. Burns, J.H. The Light of Reason: Philosophical History in the Two Mills. In James and John Stuart Mill-Papers of the Centenary Conference; Robson, J., Laine, M., Eds.; University of Toronto Press: Toronto, ON, Canada, 1976; pp. 3-20.

27. Mill, J.S. Newspaper Writings: December 1822-July 1831; Robson, A., Robson, J., Eds.; University of Toronto Press- Routledge and Kegan Paul: Toronto, ON, Canada, 1986; p. 252.

28. Harris, A. John Stuart Mill's Theory of Progress. Ethics 1956, 66, 157-175. [CrossRef]

29. Wilson, F. Mill on Psychology and the Moral Sciences. In The Cambridge Companion to Mill; Skorupski, J., Ed.; Cambridge University Press: Cambridge, UK, 1998; pp. 203-254.

30. Cairns, J. 'Introduction' in J.S. Mill. In Essays on French History and Historians; Robson, J., Ed.; University of Toronto Press-Routledge and Kegan Paul: Toronto, ON, Canada, 1985; Volume vii-xciii, p. xxvii.

31. Mill, J.S. Essays on Politics and Society; Robson, J.M., Ed.; University of Toronto Press- Routledge and Kegan Paul: Toronto, ON, Canada, 1977.

32. Beate, J. Barbarian Thoughts: Imperialism in the Philosophy of John Stuart Mill. Rev. Int. Stud. 2005, 31, 599-618.

33. Mill, J.S. Principles of Political Economy with Some of their Applications to Social Philosophy; Longmans-Green and Co: London, UK; New York, NY, USA; Toronto, ON, Canada, 1909.

34. Mill, J.S. A System of Logic Ratiocinative and Inductive. Being a Connected View of the Principles of Evidence and the Methods of Scientific Investigation; Longmans-Green and Co: London, UK; New York, NY, USA; Toronto, ON, Canada, 1889.

35. Zouboulakis, M. John Stuart Mill's Institutional Individualism. Hist. Econ. Ideas 2002, 10, 1-17.

36. Persky, J. Retrospectives: The Ethology of Homo Economicus. J. Econ. Perspect. 1995, 9, 221-231. [CrossRef]

37. Buckle, H. History of Civilisation in England; Cambridge University Press: Cambridge, UK, 2011; Volume I, p. 307.

38. Martin, J. Hegemony and the crisis of legitimacy in Gramsci. Hist. Hum. Sci. 1977, 10, 37-56. [CrossRef]

39. Robson, J. Civilisation and Culture as Moral Concepts. In The Cambridge Companion to Mill; Skorupski, J., Ed.; Cambridge University Press: Cambridge, UK, 1998; pp. 338-371.

40. Mill, J.S. Essay on Economics and Society; Robbins, L., Ed.; University of Toronto Press- Routledge and Kegan Paul: Toronto, ON, Canada, 1967; Volume II.

41. DesRoches, C.T. What is Natural about Natural Capital during the Anthropocene? Sustainability 2018, 10, 806. [CrossRef]

42. Marwah, I. Complicating Barbarism and Civilisation: Mill's Complex Sociology of Human Development. Hist. Political Thought 2011, 32, 345-366.

43. Zouboulakis, M. Democratic Representation and Economic Progress in the work of J.S. Mill. In Proceedings of the 20th Annual Conference of ESHET, Paris, France, 26-28 May 2016; pp. 1-13.

44. Mill, J. The History of British India; Wilson, H.H., Ed.; Pipper, Stephenson and Spence: London, UK, $1958 ;$ p. 72.

45. Mill, J.S. Essays on Ethics, Religion and Society; Robson, J.M., Ed.; University of Toronto Press- Routledge and Kegan Paul: Toronto, ON, Canada, 1969. 